\title{
Erratum to: Exogenous Adipokine Peptide Resistin Protects Against Focal Cerebral Ischemia/Reperfusion Injury in Mice
}

\author{
Jiangtao $\mathrm{Zhu}^{1} \cdot \mathrm{Di} \mathrm{Wu}^{1} \cdot \mathrm{Chenyu}_{\mathrm{Zhao}}{ }^{1} \cdot \mathrm{Man} \mathrm{Luo}^{1} \cdot$ Ronald C. Hamdy $^{3}$. \\ Balvin H. L. Chua ${ }^{3}$ Xingshun $\mathrm{Xu}^{1,2} \cdot$ Zhigang Miao $^{2}$
}

Published online: 25 July 2017

(C) Springer Science+Business Media, LLC 2017

\section{Erratum to: Neurochem Res}

DOI 10.1007/s11064-017-2326-5
Fig. 5A (ATP level) is wrong. The corrected Fig. 5 is given below.

The original version of this article unfortunately contained a mistake. The presentation of $\mathrm{x}$-axis coordinates of
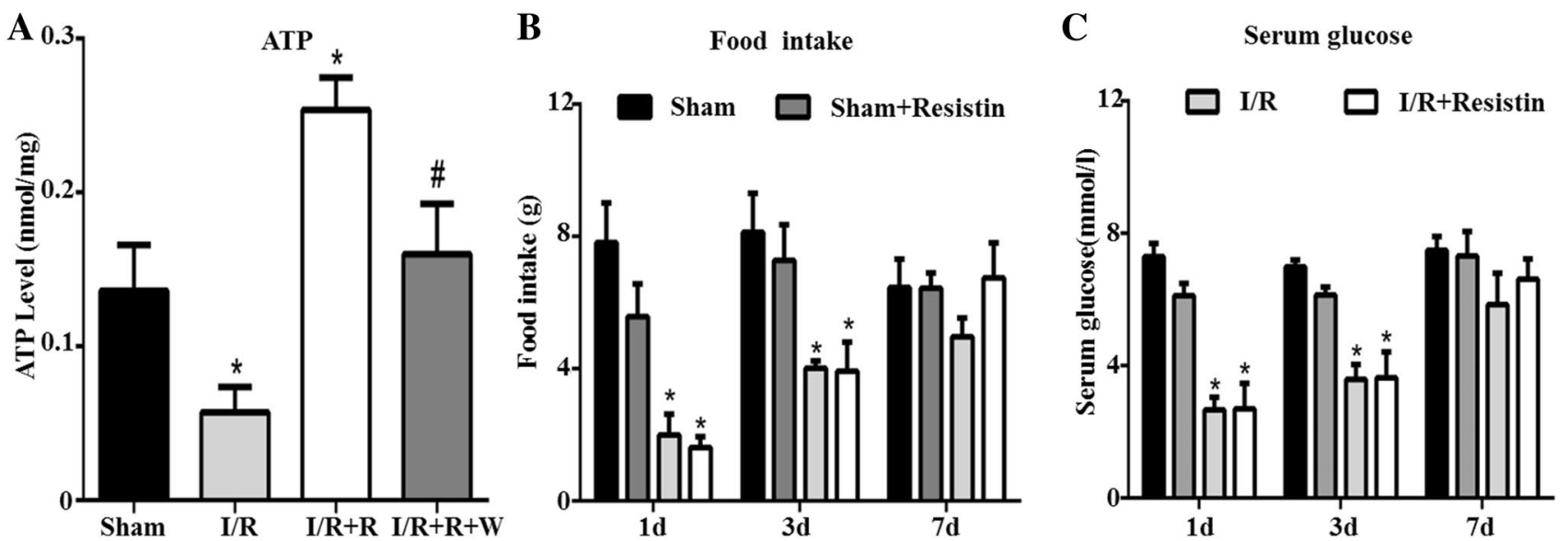

Fig. 5 Resistin treatment increased cellular ATP level after MCAO. ATP levels in ischemic brain tissues were measured at $24 \mathrm{~h}$ after MCAO (a). The food intake was recorded at 1, 3, and 7 days after
MCAO (b). Serum glucose was also measured at 1, 3, and 7 days after MCAO (c). $\mathrm{N}=6, * \mathrm{P}<0.05$, versus sham group; $\# \mathrm{P}<0.05$, versus $\mathrm{I} / \mathrm{R}+\mathrm{R}$ group

The online version of the original article can be found under doi:10.1007/s11064-017-2326-5.

Zhigang Miao

sxmiaomiao@163.com

Xingshun $\mathrm{Xu}$

Xinshunxu@suda.edu.cn

1 Department of Neurology, The Second Affiliated Hospital of Soochow University, Suzhou City, China
2 Institute of Neuroscience, Soochow University, Suzhou City, Jiangsu, China

3 Cecile Cox Quillen Laboratory of Geriatrics, James H. Quillen College of Medicine, East Tennessee State University, Johnson City, TN 37614, USA 